\title{
Book Review: The End of Patriarchy: Radical Feminism for Men by Robert Jensen
}

Heather Brunskell-Evans

Kings College, University of London, heatherbrunskellevans@gmail.com

Follow this and additional works at: https://digitalcommons.uri.edu/dignity

Part of the Feminist, Gender, and Sexuality Studies Commons

\section{Recommended Citation}

Brunskell-Evans, Heather (2017) "Book Review: The End of Patriarchy: Radical Feminism for Men by Robert Jensen," Dignity: A Journal of Analysis of Exploitation and Violence: Vol. 2: Iss. 2, Article 4. https://doi.org/10.23860/dignity.2017.02.02.04

This Book Review is brought to you for free and open access by DigitalCommons@URI. It has been accepted for inclusion in Dignity: A Journal of Analysis of Exploitation and Violence by an authorized editor of DigitalCommons@URI.For more information, please contact digitalcommons-group@uri.edu. 


\title{
Book Review: The End of Patriarchy: Radical Feminism for Men by Robert Jensen
}

\begin{abstract}
This book is a story of one man's journey through patriarchy, and his reflections on the issues of masculinity, sexuality, rape, pornography, prostitution, and transgenderism. Robert Jensen's latest book The End of Patriarchy: Radical Feminism for Men (2017) is written from his own gender location as a man who became persuaded by the intellectual and political coherence of radical feminism. In focusing on contemporary issues of sexuality/gender, he tackles topics that are controversial not only in the dominant culture but within feminism itself. In exploring these from a radical feminist perspective, he pin-points the crucial differences between radical feminism and liberal/postmodern feminisms. He compellingly argues that a radical feminist ethics, rooted in a shared moral commitment to human dignity, solidarity, and equality, offers an escape from the pathology of patriarchy. Jensen writes with ease, never letting go of a mode of analysis anchored in his embodied subjectivity. The book is paradoxically uplifting, given the weightiness of its topics, because it is fundamentally concerned with the broader themes of humanity and the possibilities for freedom.
\end{abstract}

\section{Keywords}

patriarchy, radical feminism, masculinity, sexuality, rape, pornography, prostitution, transgenderism, freedom, humanity

\section{Creative Commons License}

\section{(c) (i) (9)}

This work is licensed under a Creative Commons Attribution-Noncommercial-No Derivative Works 4.0 License. 


\section{DIGNITY}

Volume 2, Issue 2, Article 4, 2017
A JOURNAL ON

SEXUAL EXPLOITATION

AND VIOLENCE

\title{
BOOK REVIEW: THE END OF PATRIARCHY: RADICAL FEMINISM FOR MEN BY ROBERT JENSEN SPINIFEX PRESS, NORTH MELBOURNE, AUSTRALIA, 2017, 200 PAGES
}

\author{
Heather Brunskell-Evans \\ King's College, University of London
}

\begin{abstract}
This book is a story of one man's journey through patriarchy, and his reflections on the issues of masculinity, sexuality, rape, pornography, prostitution, and transgenderism. Robert Jensen's latest book The End of Patriarchy: Radical Feminism for Men (2017) is written from his own gender location as a man who became persuaded by the intellectual and political coherence of radical feminism. In focusing on contemporary issues of sexuality/gender, he tackles topics that are controversial not only in the dominant culture but within feminism itself. In exploring these from a radical feminist perspective, he pinpoints the crucial differences between radical feminism and liberal/postmodern feminisms. He compellingly argues that a radical feminist ethics, rooted in a shared moral commitment to human dignity, solidarity, and equality, offers an escape from the pathology of patriarchy. Jensen writes with ease, never letting go of a mode of analysis anchored in his embodied subjectivity. The book is paradoxically uplifting, given the weightiness of its topics, because it is fundamentally concerned with the broader themes of humanity and the possibilities for freedom.
\end{abstract}

\section{KEYWORDS}

Patriarchy, radical feminism, masculinity, sexuality, rape, pornography, prostitution, transgenderism, freedom, humanity

I

TOOK ROBERT JENSEN'S latest book-The End of Patriarchy: Radical Feminism for Men (2017)-to a radical feminist residential weekend gathering. After 24 hours of living together, strategizing and sharing personal stories, we were all somewhat exhausted after lunch one day. We were chatting lazily about this and that, with the spring sun pouring through the window. Someone picked up my copy of Jensen's book from the coffee table, and she idly remarked "Oh no, not another bloke telling radical feminists about their own movement and lecturing us on our own theories." I was suddenly galvanized to sit upright on the sofa where I had been dozing. I found myself passionately defending both the author and the book. "It really isn't like that at all," I insisted. "Jensen is describing his own journey with radical feminism, not as our 'chivalrous defender,' 
and not expecting a 'nice guy accolade,' but more selfishly, because radical feminism helped save his life." There and then I realized I had relayed the book's heartbeat, and that if I had to sum the book up in one sentence, I had just done so.

The book is broadly divided into three themes, interweaving Jensen's personal, intellectual and political engagement with radical feminism. Firstly, he describes his life as cleaving neatly into two halves. In the first 30 years, he desperately tried to be 'normal,' to fit in, to be 'a man,' to be 'realistic' about how the world worked, but these strategies left him miserable. In the second 30 years, he has tried to face his fears and to understand the sources of that misery both in the particularities of his own personal circumstances and in the systems that structure society. His earliest understanding of radical feminism led him to attempt to give himself permission for his "feminine side." He later realized the dichotomy 'masculinity' and 'femininity' does not enable release from the domination/subordination dynamic. He tells us radical feminism eventually "taught me how to analyze that dynamic rather than to capitulate... Feminism, I came to understand, was not a threat to men but a gift to us" (p. 71).

Secondly, Jensen explains that initially he intellectually repudiated the key concepts of radical feminist thought: Patriarchy is a brutal sex/gender system that sexualizes domination and subordination. Patriarchal power is the ability of men as a class to exercise 'power-over' women as a class. Patriarchal power is exercised in all areas of our private and public life, but particularly through the control of women's sexuality and reproductive capacities, backed by violence. He analyzed these propositions as unfounded, ideological, and even hysterical. Despite his immediate disparagement, he began to realize feminist ideas spoke to his private loneliness and alienation, suggesting ways to untangle the ties that had bound him since boyhood. Later he came to embrace radical feminist thought for its intellectual coherence, and because it helped him bring together his intellectual and embodied self.

Jensen devotes three chapters to contemporary issues that are controversial not only in the dominant culture but within feminism itself: (i) rape and sexual intrusion; (ii) prostitution and pornography; and (iii) transgenderism and the biological and political claims of the transgender movement. In exploring these from a radical feminist perspective, he pin-points the crucial differences between radical feminism and liberal/postmodern feminisms. For anyone confused about the theoretical differences and political stakes, Jensen clarifies them with ease, never letting go of a mode of analysis anchored to his embodied subjectivity.

Although liberalism and postmodernism are rooted in very different theories and sets of assumptions, Jensen illuminates how they are similar in their practical commitment to individualism in politics. Liberal and postmodern feminisms focus on how women's choices within patriarchy can be 'empowering.' In contrast, radical feminism offers a blunt assessment of patriarchy and demands that we work for dramatic changes, not only in public policy but in our personal lives and ways of thinking about ourselves. The radical feminist goal is revolutionary: it does not advocate liberal accommodation but an end to the cultural normalization of the gender/sexual hierarchy.

Thirdly, Jensen proposes that radical feminism leads to a deeper critique of structures of power more generally. Radical feminism identifies how patriarchal societies tend to treat all relationships as a site of struggle for domination. Patriarchal pathology, for example, is at the core of our current ecological crisis and the 
threat to the ecosphere from unsustainable human systems. He compellingly argues that a radical feminist ethics, rooted in a shared moral commitment to human dignity, solidarity, and equality, offers a different way of living our humanity. Toxic masculinity not only subordinates women but cripples men's "own capacity to be fully human" (p. 71). Comprehending the dynamics of patriarchy and devising strategies of resistance are painful. Nevertheless, he remains true to a pledge to be honest in his assessment of how the world works and to be self-critical about his own life. "To turn away from that task is to turn away from our own humanity" (p.166).

In conclusion, Jensen has explored radical feminist ideas about rape culture, the sexualization of women's subordination in pornography and prostitution, and the politics of transgenderism. Liberal/postmodern advocacy of 'choice feminism,' and its repudiation of radical feminist insights into these issues, indicates the depth to which patriarchy is deeply woven into the fabric of contemporary life. The existence of patriarchy is hard for men to countenance, including those liberal men who endorse women's equality. Radical feminism causes men to reflect upon their privilege and status, demanding they re-assess their assumptions about what it means to be a man, including what it means to be a sexual man and to give up their unearned 'power-over.' Whether Jensen still needs courage to intervene into the vexed and sometimes brutally acrimonious debates within gender/sexual politics, he has put his head above the 'manly' parapet that defends itself against radical feminism. I recommend this book precisely because it is written by a man who reflects upon patriarchy as a social structure that dehumanizes both men and women, and who does so without asserting a false equivalence between men's experiences and the threats that women face and the injuries we experience.

\section{AUTHOR BIOGRAPHY}

Heather Brunskell-Evans, Ph.D., is a Visiting Senior Research Fellow at King's College, London. She is a social theorist whose special interest is the philosophy and politics of the gendered/sexed body. She has a special interest in the work of Michel Foucault and Andrea Dworkin. She is a trustee of FiLia, a new feminist charity where she is director of its Stop Violence against Women and Girls section. She was co-founder (2013) of 'Resist Porn Culture,' a UK organization set up to challenge the pornography industry and the pornification of culture, originally linked to Culture Reframed, USA, and now under the auspices of FiLia. She is the National Spokesperson for the Women's Equality Party policy on sexual violence. She has published extensively in popular media. Her latest books include: (2016) The Sexualized Body and the Medical Authority of Pornography, Cambridge Scholars; (forthcoming 2017) Internet Pornography: Disciplining Women Through Sexual Freedom (Palgrave MacMillan), and (forthcoming 2017) Transgender and Children: Born in Your Body (Cambridge Scholars).

\section{RECOMMENDED CITATION}

Brunskell-Evans, Heather. (2017). Book review: The end of patriarchy: Radical feminism for men by Robert Jensen. Dignity: A Journal of Sexual Exploitation and Violence. Vol.

2, Issue 2, Article 4. doi:10.23860/dignity.2017.02.02.04. Available at http://digitalcommons.uri.edu/dignity/vol2/iss2/4. 